\title{
Detection of drug resistant bacteria in different ice creams available in local market of Dhaka city
}

\author{
Md. Musa Howlader and Tahmina Shammi* \\ Department of Microbiology, Stamford University Bangladesh, 51 Siddeswari Road, Dhaka 1217, Bangladesh
}

Received 09 August 2017/Accepted 17 September 2017

\begin{abstract}
Sound microbiological quality of ice cream should be ensured for being a widely popular dairy food in the world. Present study was conducted to determine the microbiological quality of different ice cream samples available in Dhaka, Bangladesh. Total 3 ice cream samples were collected and processed to detect the microbiological quality as well as drug resistant trait of the isolates through several conventional Kirby Bauer method. All the samples were found to be contaminated with the total viable bacteria and fungi within the range of $1.2 \times 10^{4} \mathrm{cfu} / \mathrm{ml}^{\text {to }} 4.3 \times 10^{6} \mathrm{cfu} / \mathrm{ml}$. The presence of $E$. coli, Staphylococcus aureus was also observed up to $10^{4} \mathrm{cfu} / \mathrm{ml}$. However, the fecal contamination was totally absent in all the samples. Antibiotic profile of two isolates was measured against 8 commonly used antibiotics and both E.coli and Staphylococcus aureus were found to be resistant against more than one antibiotics. Appropriate hygienic and storage condition should be maintained concerning the health safety of consumers.
\end{abstract}

Key words: Ice Cream; Contamination; Drug Resistance

Being a tropical country, Bangladesh usually has long summer periods and the ice cream consumption rate increases in a large amount on that time. Ice cream is a very popular ready to eat frozen dairy food. It is consumed by people of all ages and so it should be microbiologically safe because the huge popularity of this food item among the children (1). On the basis of several previous studies, the microbiological quality of ice cream samples in Bangladesh is not quite satisfactory from the public health perspective (2). The poor quality of ice cream samples in Bangladesh have been observed at some previous studies conducted on available ice cream samples in the market at different cities (3).

Milk, sweetening, stabilizing agents with colorings and flavorings are the main ingredients of ice cream (4) and presence of these rich ingredients makes ice cream a nutritious food item for human as well as a perfect medium for growth of many pathogenic microorganisms (5). Along with the high milk content, the nearly neutral $\mathrm{pH}$ value also makes ice cream an ideal medium for bacterial growth (6). These pathogens sometimes can survive pasteurization and cause outbreaks of food borne diseases like cholera, typhoid, diarrhea, listeriosis etc. (7).

Along with the faulty manufacturing process, the raw materials used for the production of sometimes serve as

*Corresponding Author: Mailing address. Tahmina Shammi, Senior Lecturer Department of Microbiology, Stamford University Bangladesh, 51 Siddeswari Road, Dhaka 1217, Bangladesh, Bangladesh; E-mail: tahminashammi@yahoo.com. a main source of bacterial contamination to the ice creams (8). Besides these, leakage in the processing tanks, post sterilization contamination, improper storage conditions, faulty packaging process and transportation ways contributes the presence of pathogens into these products (9). Presence of pathogenic bacteria like: Listeria monocytogenes, Staphylococcus aureus, Salmonella spp, Shigella spp and coliform bacteria enhance the potential threat to ice cream quality for human $(1,10)$.

On the other hand, the constant failures of antibiotics on pathogens due to the presence of resistance genes in the developing countries compelled the researchers to establish the common bacterial species that occur in the dairy products (especially ice cream) and their antibiotic resistance patterns (11). This study was designed to determine the microbiological properties and antibiotic susceptibility pattern of the resistant bacteria present in the Ice Cream samples.

\section{MATERIALS AND METHODS}

Sampling plan. This study was carried out during the summer period at Dhaka, Bangladesh. In this time, people consume ice cream in a large amount. Three Ice Cream samples of different brands were collected from the local market of Shantinagar randomly. The samples were aseptically collected from $-16^{\circ} \mathrm{C}$ refrigerator and the valid expiry dates and intact seals were ensured. The collected ice cream samples were then transported to the laboratory as soon as possible for further experiments by following the method suggested by American Public Health Association (12)

Samples preparation and processing. After transportation of the ice cream samples to the laboratory, we kept these in the water bath at $45^{\circ} \mathrm{C}$ for the thawing process. The top parts of the packets were opened carefully and samples were collected by using a sterile micro pipette aseptically when the samples became liquid completely $(13,14)$. Afterwards, each of the collected samples were 
transferred to $9 \mathrm{ml}$ normal saline in sterile test tubes (15). The samples were then diluted up to $10^{5}$ dilutions for the enumeration of total viable bacterial count.

Microbiological Analyses. For the enumeration of total viable bacterial count (TVBC), an aliquot of $0.1 \mathrm{ml}$ from $10^{-3}$ dilutions of each sample were introduced onto the nutrient agar (NA) plates by the spread plate technique (16, 17). After that, the inoculated nutrient agar plates were incubated at $37{ }^{\circ} \mathrm{C}$ for 24 hours. For the enumeration of fecal coliform count, an aliquot of $0.1 \mathrm{ml}$ from $10^{2}$ dilutions of each sample were introduced onto the m-FC agar plates by the spread plate technique and incubated at $44.5^{\circ} \mathrm{C}$ for 24 hours.

An aliquot of $0.1 \mathrm{ml}$ from $10^{-2}$ dilutions of each sample were introduced onto MacConkey agar and Manitol Salt agar plates by the spread plate technique for the enumeration of total coliform and Staphylococcus aureus. The inoculated agar plates were then kept at $37{ }^{\circ} \mathrm{C}$ in an incubator for 24 hours. And, for the detection of any fungal count, an aliquot of $0.1 \mathrm{ml}$ from $10^{-3}$ dilutions of each samples were introduced onto the Saboured Dextrose Agar plate by following the spread plate method and incubated at $25^{\circ} \mathrm{C}$ for 48 hours.

Antibiotic susceptibility testing. The disc diffusion method was applied to determine the antibiotic susceptibility of the isolated E.coli and Staphylococcus colonies (18). Muller Hington (MH) Agar plates were used for this experiment and the agar plates were seeded by earlier prepared cell suspension with a turbidity of $0.5 \mathrm{McF}$ arland standards. The suspensions were streaked onto the $\mathrm{MH}$ agar plates by sterile cotton swabs carefully. After that, the antibiotic discs were placed on the agar plates and kept at $30{ }^{\circ} \mathrm{C}$ for 24 hours in the incubator. Total eight types of antibiotics were used for the experiment. They are: Oxacillin (OX1), Kanamycin (K30), Ampicillin (AM10), Cefixime (CFM5), Erythromycin (E15), Azithromycin (AZM30), Tetracycline (TE 30) and Chloramphenicol (C30). After the incubation period, the zones of inhibition were measured and recorded (11).

\section{RESULTS AND DISCUSSIONS}

In the present study we detected total viable bacterial count, total coliform count, Staphylococcus aureus count, total fungal count and total fecal coliform count in three ice cream samples. Total viable bacteria ranged from $2.26 \times 10^{6} \mathrm{cfu} / \mathrm{ml}$ to $4.3 \times 10^{6} \mathrm{cfu} / \mathrm{ml}$. Total coliform count was ranged from $1.1 \times 10^{4} \mathrm{cfu} / \mathrm{ml}$ to $8 \times 10^{3}$ $\mathrm{cfu} / \mathrm{ml}$. Rahman et al. (2) reported the differential distribution of microbial contaminations on various ice cream samples. On that study, the highest total viable bacterial count was $9.5 \times 10^{4} \mathrm{cfu} / \mathrm{ml}$ and the maximum total fecal coliform count was $4 \mathrm{cfu} / \mathrm{ml}$ whereas in this study there was no fecal coliform present in the ice cream samples. Total Fungal Growth ranges from $1.2 \times 10^{4} \mathrm{cfu} / \mathrm{ml}$ to $1.7 \times 10^{4} \mathrm{cfu} / \mathrm{ml}$. The presence of Staphylococcus aureus was from $1.2 \times 10^{4} \mathrm{cfu} / \mathrm{ml}$ to $7 \times 10^{3} \mathrm{cfu} / \mathrm{ml}$ and the reason could be, their widespread presence in the environment. The human nasal cavity and skin is their largest reservoir and they disseminates in the contacted dust, air and food products (10). (Table 1).

Antibiotics are natural or semi synthetic of synthetic drugs which has the ability of killing bacteria and fungus. For the treatment of food poisoning and infection, keeping track of medically important antibiotics by the antibiotic susceptibility test of food products is necessary (11). Table 2 shows the zone diameter of inhibition of the selected antibiotics against 2 isolated bacteria from 3 ice cream samples. The degree of susceptibility of these test organisms to each antibiotic was determined and

TABLE 1. Microbial Prevalence of microorganisms in ice cream samples (cfu/ml)

\begin{tabular}{llllll}
\hline $\begin{array}{l}\text { Ice Cream } \\
\text { Sample }\end{array}$ & $\begin{array}{l}\text { Total Viable } \\
\text { Count }\end{array}$ & $\begin{array}{l}\text { Total } \\
\text { Staphylococcus } \\
\text { Count }\end{array}$ & $\begin{array}{l}\text { Total Coliform } \\
\text { Count }\end{array}$ & $\begin{array}{l}\text { Total Fecal } \\
\text { Coliform Count }\end{array}$ & $\begin{array}{l}\text { Total Fungi } \\
\text { Count }\end{array}$ \\
\hline Brand 1 & $3.65 \times 10^{6}$ & $1.2 \times 10^{4}$ & $4 \times 10^{3}$ & Nil & $1.2 \times 10^{4}$ \\
Brand 2 & $4.3 \times 10^{6}$ & $7 \times 10^{3}$ & $8 \times 10^{3}$ & Nil & $1.7 \times 10^{4}$ \\
Brand 3 & $2.26 \times 10^{6}$ & $1.3 \times 10^{4}$ & $1.1 \times 10^{4}$ & Nil & $1.2 \times 10^{4}$ \\
\hline
\end{tabular}

TABLE 2. indicates the Sensitivity of the E. Coli and Staphylococcus aureus isolates against 8 commonly used antibiotics

\begin{tabular}{ccccccc}
\hline \multirow{2}{*}{ Antibiotics } & \multicolumn{3}{c}{ E. coli } & \multicolumn{3}{c}{ Staphylococcus aureus } \\
\cline { 2 - 7 } & R & I & S & R & I & S \\
\hline OX1 & $100 \%$ & $0 \%$ & $0 \%$ & $0 \%$ & $0 \%$ & $100 \%$ \\
K30 & $0 \%$ & $0 \%$ & $100 \%$ & $0 \%$ & $0 \%$ & $100 \%$ \\
AM10 & $100 \%$ & $0 \%$ & $0 \%$ & $0 \%$ & $0 \%$ & $100 \%$ \\
CFM5 & $0 \%$ & $0 \%$ & $100 \%$ & $0 \%$ & $0 \%$ & $100 \%$ \\
E15 & $100 \%$ & $0 \%$ & $0 \%$ & $100 \%$ & $0 \%$ & $0 \%$ \\
AZM30 & $0 \%$ & $0 \%$ & $100 \%$ & $100 \%$ & $0 \%$ & $0 \%$ \\
TE30 & $100 \%$ & $0 \%$ & $0 \%$ & $0 \%$ & $0 \%$ & $100 \%$ \\
C30 & $0 \%$ & $0 \%$ & $100 \%$ & $0 \%$ & $0 \%$ & $100 \%$ \\
\hline
\end{tabular}

$\mathrm{OX} 1=$ Oxacillin, $\mathrm{K} 30=$ Kanamycin, AM10= Ampicillin, CFM5= Cefixime, E15=Erythromycin, AZM30= Azithromycin, TE30= Tetracycline and $\mathrm{C} 30=$ Chloramphenicol.

$\mathrm{R}=$ Resistant, $\mathrm{I}=$ Intermediate, $\mathrm{S}=$ Sensitive . 
interpreted as sensitive (S), resistant (R) or intermediate (I) by calculating zones of inhibition around the antibiotic discs (19). Study of antibiogram showed that isolated E. coli. was resistant to 4 antibiotics- OX1, AM10, E15 and TE30, while, Staphylocaccus aureus was resistant against 2 antibiotics (E15 and AZM 30) and there was no intermediate response against the antibiotics by any of these isolates. Both E. coli and Staphylococcus aureus were resistant against Erythromycin only which is similar to a recent study conducted by Nwinyi et al, (11).

\section{CONCLUSION}

Along with the contamination of different pathogenic bacteria in available ice cream samples, the resistance ability of these pathogens is increasing in an alarming rate day by day. More focus should be tuned for controlling multidrug resistance of pathogens isolated from food samples. Proper manufacturing protocols should be ensured during the processing, transportation and handling of food products to decline the contamination which can act as perilous for the human being after consumption

\section{ACKNOWLEDGEMENT}

Special thanks to Microbiology Laboratory, Stamford University Bangladesh for laboratory facilities, technical assistance and financial aid.

\section{REFERENCES}

1. Warke RA, Kamat $\mathbf{M}$ and Kamat PJ. 2000. Incidence of pathogenic psychrotrophs in ice creams sold in some retail outlets in Mumbai. India Food Contr. 11: 77-83.

2. Rahman T, Sharma BC and Isalam MN. 2015. Microbiological Profiling of Ice Cream Samples Sold in the Retail Shops in Dhaka City. Bangladesh J Microbiol. 32 (1, 2): 45-48.
3. Hossain KMM, Kabir SML, Rahman MM, Rahman MB, Choudhury KA. 2012. Organoleptic and microbial quality of ice cream 94 sold at retail stores in Mymensingh, Bangladesh. J Microbio Res. 2 (4): 89-94.

4. Akter S and Ahmed S. 2012. Bacterial Analysis of Different Types of Ice Creams from Dhaka City. Bangladesh J Microbiol. 29 (1): 41-43.

5. Frazier WC and DC Westhoff. 1998. Contamination, Preservation, and Spoilage of Milk and milk Products. In Food Microbiology, pp. 276-299. McGraw-Hill, New York.

6. Bigalke D, Chappel R. 1984. Ice cream microbiological quality. Controlling and other microbial contamination in ice cream. Dairy Food Sanit. 4: 318319.

7. Buvens G, Posse B, Schrijver KD, Zutter LD, Lauwers $\mathbf{S}$ and Denis $\mathbf{P}$. 2011. Virulence Profiling and Quantification of Verocytotoxin-Producing Escherichia coli O145: $\mathrm{H} 28$ and O26:H11 Isolated During an Ice CreamRelated Hemolytic Uremic Syndrome Outbreak. Foodbrone Path. Dis. 8 (3): 421-426.

8. Williams ED. 1984. Manual on milk and milk products testing procedures, Bangladesh. The Food and Agriculture Organization of the United Nations.

9. Joshi DR, Shah PK, Manandhar S, Sharma S and Banmali P. 2004. Microbial quality of ice cream sold in Kathmandu. J. Nepal Heal. Res. Coun. 2 (2): $37-40$.

10. Jay JM. 1992. Modern Food Microbiology, Fourth edition. Chapman and Hall Inc., New York.

11. Nwinyi OC, Obehi E, Tomilola A, Oniha MI, Bunmi O. 2017. Antibiotic susceptibility patterns of bacteria species isolated from ice-cream vended in Ota and Lagos Metropolis. Research Journal of Microbiology. 12 (1): 50-57.

12. American Public Health Association. 1998. Standard Methods for the Examination of Water and Wastewater. American Public Health Association, Washington, D.C.

13. Harrigan MF and McCance ME. 1976. Laboratory methods in food and dairy microbiology. Academic Press, London, England.

14. Rahman MM. 1997. Practical food microbiology. Bangla Academy, Dhaka Bangladesh.

15. Tabassum S, Uddin MA. 2016. Microbiological analysis of different flavoured milk samples collected from various areas of Dhaka city, Bangladesh. Bangladesh J Microbiol. 33 (1, 2): 11-15.

16. Marjan S, Kanta KD, Munshi SK, and Noor R. 2014. Drug-resistant bacterial pathogens in milk and some milk products. Nutn. Food Sci. 44 (3): 241-248.

17. Malek M, Akter J, Ahmed T, Uddin MA. 2015. Isolation and quantification of microorganisms from some common milk products within Dhaka city, Bangladesh. Stamford J. Microbiol. 5 (1): 13-17.

18. Oyetibo GO, Ilori MO, Adebusoye SA, Obayori OS, Amund OO. 2010 Bacteria with dual resistance to elevated concentrations of heavy metals and antibiotics in Nigerian contaminated systems. Environ. Monit. Assess. 168 (1-4): 305-14.

19. Akubuenyi FC, Arikpo GE, Ogugbue CJ, Mfongeh J.F, Akpanumun E.V. 2011. Antibiotics resistance profile of waste water isolates obtained from University of Calabar Teaching Hospital and General Hospital, Calabar, Nigeria. Nig. J. Microbiol. 25: 2243-2250. 